\title{
Enterprise Risk Management and Its Effect on Firm Value in Turkey
}

\author{
Dr. Özlem SAYILIR (Corresponding author) \\ Faculty of Business Administration Anadolu University \\ Yesiltepe, Anadolu Üniversity, Eskisehir 26470, Turkey \\ Tel: 90-222-335-0580Ｅ-mail: osayilir@anadolu.edu.tr \\ Muhammad FARHAN \\ Faculty of Business Administration Anadolu University \\ Yesiltepe, Anadolu Üniversity, Eskisehir 26470, Turkey
}

Tel: 90-222-335-0580Ｅ-mail: farhan_fuu@yahoo.com

Received: Oct. 7, 2016 Accepted: Dec. 22, $2016 \quad$ Published: January 1, 2017

doi:10.5296/jmr.v9i1.10124 URL: http://dx.doi.org/10.5296/jmr.v9i1.10124

\begin{abstract}
Enterprise Risk Management (ERM)is an integrated risk management approach, which considers risks in the context of business strategy and manages them with a portfolio perspective through well defined risk responsibilities and strong risk monitoring processes. The purpose of this study is to examine the impact of ERM on firm value for 130 firms operating in the manufacturing industry and listed in Borsa Istanbul. For this purpose, we utilized panel regression models on financial data collected in the period 2008-2013. The dependent variable is Tobin's $Q$, which is used as a proxy of firm value. The independent variable is ERM implementation, whereas the control variables are firm size, leverage ratios and profitability ratios. We tested the hypothesis that there is a relationship between ERM and firm value. Our findings suggest that there seems to be no statistically significant relationship between firm value and ERM. We also employed a survey to explore how firms implement ERM and to obtain information about motivation behind adoption of ERM, challenges of ERM implementation and effects of ERM adoption.
\end{abstract}

Keywords: Enterprise Risk Management, Chief Risk Officer, Firm Value, Tobin's Q 


\section{Introduction}

21 st century is an era of continuous change. People have been witnessing enormous transformations in all fields of social and economic life. Businesses are trying to survive and succeed in a world of uncertainties arising from the mega trends of globalization, technological advances and changing structure of markets. Hence, businesses are becoming exposed to a wide variety of risks in their operations and risk management has become a significant field of research especially after the global financial crises of 2008. Risk models used before 2007 and 2008 proved to fail. 2008 crisis occurred due to weak regulations in capital markets and contagion risks and it strengthened the importance of risk management (Jorion, 2009).

Financial risks have been controlled through hedge funds and other tools over the years, often by investment banks. In time, it was realized that many risks could be prevented or their impact reduced, through loss prevention and control systems. These finding led firms to a broader view of risk management. Enterprise Risk Management (ERM) approach has emerged to provide the means to recognize and mitigate risks with a holistic approach. Businesses have started adopting ERM programs, rating agencies have started to consider ERM approach in rating processes, universities have started to offer ERM courses and establish research centers (Hoyt \& Lienberg, 2011).

"Enterprise risk management is a process, affected by an entity's board of directors, management and other personnel, applied in a strategy setting and across the enterprise, designed to identify potential events that may affect the entity, and manage risk to be within its risk appetite, to provide reasonable assurance regarding the achievement of entity objectives" (Moeller, 2011).

Most of the organizations previously used to employ traditional risk management (TRM) systems or "silos" to prevent risk. In TRM systems, individuals are not held responsible from identification and assessment of risks, but instead they focus on discrete risks only. On the contrary, in ERM systems, risk is viewed in the context of business strategy, and managed with well-defined risk responsibilities and strong risk monitoring processes(Banham \& Basics, 2004).

The main difference between ERM approach and the traditional risk management (TRM) approach is integration and isolation. ERM manages risks in an integrated way, while TRM treats them as a "silo" or "stovepipe". ERM provides the platform to harmonize the goal of balancing enterprise's portfolio of risks with stakeholders' appetite for risk. (Fraser \& Simkins, 2010).

There are some organizational aspects which make ERM different from traditional risk management approaches. Firstly; ERM suggests having a formal report which is submitted to board level at least annually on the current state of, and effectiveness of the risk management program. In ERM, there is also a senior level position usually called "Chief Risk Officer" (CRO), who has the highest responsibility for overseeing the centralized risk management function and who is independent of risk taking activities and decisions. CRO assumes ownership of the risk management program and reports directly to the top of the organization. Moreover, a board level committee with pure responsibility for risk management oversight is 
another key element in the ERM process. Furthermore, ERM has a formal written risk management philosophy (policy), which refers to a set of shared beliefs and attitudes characterizing how the firm considers risk in everything it does and describes responsibility of management and board. A formal written statement of the firm's risk appetite, which is the amount of risk specified at board level that the firm is willing to accept in pursuit of value, is also considered to be essential in ERM implementation. A centralized department or staff function dedicated to risk management is another component of ERM. ERM also suggests allocating risk owners who have primary responsibility and accountability for managing risk within their respective areas. Lastly, a centralized technology-enabled process to obtain risk-related information has importance in an ERM process (COSO - Executive Summary, 2004).

ERM can provide benefits beyond traditional risk management. An integrated risk management system can handle opportunities and threats effectively (Hillson, 2002). Dealing with each risk indecently is a difficult task, so the tenacity of ERM is to achieve a systematic understanding of the interdependencies and associations among risks. According to the portfolio theory, if natural hedges exist, aggregate portfolio risk should be less than the sum of the individual risks (McShane, Nair, \& Rustambekov, 2011). Return on equity and shareholder value can be improved with the help of CRO (Lam, 2014). Thus, ERM can increase firm value. The purpose of this study is to examine the impact of ERM on firm value in Turkey.

\section{Literature Review}

Some researchers proposed that ERM can reduce financial distress costs, enhance managerial risk aversion, mitigate expected tax payments, solve underinvestment problems and provide confidence for businesses to carry out new investment projects. ERM can enhance company performance by reducing the cost of capital, improving confidence of investors and also improving rating of the firm, which shows that the firm has ability to service debt under conceivable conditions (Fraser \& Simkins, 2007).(Baxter, Bedard, Hoitash, \& Yezegel, 2013) suggested that high-quality ERM programs enhance operating performance and add value to companies. Similarly, (Gatzert\& Martin, 2015) compared different studies and found that there is a positive relationship between ERM and firm value or performance. (Hoyt \& Lienberg, 2011) also suggested that ERM and business value has positive correlation.

Familiarity to risk management becomes beneficial for banks, government, board of directors, top management, and external auditors and internal auditors because ERM supports them in the implementation and evaluation of corporate policies (Dabari \& Saidin, 2014).(Gates, Nicolas, \& Walker, 2012) stated that companies take better decisions by implementing ERM process. ERM provides understanding to firms to manage risks across business units and helps them to improve equity returns and capital efficiency (Meulbroek, 2002).However, ERM process requires time to provide positive results, so companies should be patient with instant value outcome (Gates, Nicolas, \& Walker, 2012).

According to (Walker, Shenkir, and Barton, 2002), ERM not only educates management but also makes managers focus on the same page. It also helps the employees and associates to understand their main focus area.(Miccolis, Hively, Merkley, \& Perrin, 2001) suggested that a business unified system may enhance firm value by escalating more efficient channels of 
communication between divisions, cultivating capital proficiency, alleviating earnings and reducing projected expenditures of peripheral capital and regulatory.(Nocco \& Stulz, 2006) found that firms can gain long term competitive advantage as ERM provides micro level benefits to firms by determining the responsibility of risk taking on a lower level e.g. how and by whom risk is owned. In ERM, Chief Risk Officer (CRO) is responsible for all types of risks and works as a channel to communicate between upper and lower level management. This strategy involves managers in the risk management process and helps to improve capital allocation.

Effectiveness of ERM depends on the proper match between firm and ERM (Dabari \& Saidin, 2014). (Gordon, Loeb, \& Tseng, 2009)proposed the relationship between ERM and firm performance depends on environmental uncertainty, industry competition, firm size, firm complexity and monitoring by the board of directors. This implies that firms should evaluate the ERM implementation on the basis of contextual variables around the firm.

Some researchers found mixed or adverse results concerning the relationship between ERM and firm value. (McShane et al., 2011) investigated the effect of ERM on firm value and found evidence of a positive relationship between increasing level of TRM capability and firm value, but no additional firm value for firms achieving a high ERM rating. Result shows that under a certain level ERM has positive relationship with firm value, but beyond that level there is no apparent increase in firm value.(Lin, Wen, \& Yu, 2011) conducted a theoretical research and examined the effect of ERM on firm value and found that ERM implementation exhibited a significant negative correlation with firm value in terms of Tobin's Q.

\section{Data}

In our attempt to investigate the relationship between firm value and ERM, we conducted our study on manufacturing companies operating in Turkey, which are listed in Borsa Istanbul (Istanbul Stock Exchange). The data were collected from "Public Disclosure Platform web page for the period of 2008 to 2013 (6 years). The population of the study consists of 130 companies.

\subsection{ERM Engagement}

To determine if a firm that operates in the manufacturing industry in Turkey actively implements ERM, we consulted Marsh Risk Consulting (Turkey), which provides consulting services in the field of ERM implementation. Although public companies in Turkey are obliged to adopt ERM, only a small percentage of public companies are considered to be actively implementing ERM, according to expert views we received from Marsh Risk Consulting (Turkey).

\subsection{Tobin's $Q$}

Most studies use Tobin's Q as proxy of firm value (Smithson \& Simkins, 2005). Tobin's Q is a ratio that compares the market value of a firm's assets to their replacement cost (Hoyt \& Lienberg, 2011). Tobin's Q has domination on other measures such as stock returns and accounting measures because it does not require risk adjustment or normalization (Lang \& Stulz, 1994). (Cummins, Lewis, \& Wei, (2006) define Tobin's Q as the market value of equity 
plus the book value of liabilities divided by the book value of assets.

\subsection{Size}

ERM is mostly used by large firms (Beasley et al., 2005; Colquitt, Hoyt, \& Lee, 1999; Hoyt, 2003) since it is less costly for large firms as compared to small firms due to economies of scale (Beasley, Pagach, \&Warr, 2008). We use the log of the book value of assets as size of firms.

\subsection{Leverage}

We use short term debt to total asset and long term debt to total asset for the calculation of leverage.

\subsection{Return on Assets (ROA)}

Profitable firms are likely to trade at premium (Allayannis \& Weston, 2001). We use it as control variable for Tobin's Q. Net income divided by total assets is used to calculate the return on assets.

\section{Methods}

The purpose of this study is to examine the impact of ERM on firm value for firms operating in the manufacturing industry and listed in Borsa Istanbul (stock exchange). To investigate the relationship between ERM and firm value, we utilized regression models. The dependent variable is Tobin's $Q$, which is used as a proxy of firm value similar to other studies in this field (Baxter et al., 2013; Hoyt \&Lienberg, 2011; Lin et al., 2011; McShane et al., 2011). The independent variable is ERM implementation, whereas the control variables are firm size, leverage, ROA (Return on asset). We test the hypothesis that there is a relationship between ERM and firm value.

Linear regression analysis, specifically panel data modellingwas performed toanalyze the data. We used Stata 13 software to examine the data and build regression models. Regression analysis method is used to find out the effect of independent variables on the dependent variable(Song \& Kemp, 2013). We employed panel data regression analysis as our data set comprises both time series and cross sectional data.

We also utilized a survey to explore how firms implement ERM and obtain information about motivation behind adoption of ERM, challenges of ERM implementation, effects of ERM adoption etc.

\subsection{Panel Data Analysis}

Panel data analysis provides competent result for studies which consider time and space dimensions of data. It allows social science researchers to conduct longitudinal analysis in a vast variety of fields.Inthe field of political science, panel data analysis can be used to examinethe relationship political party behavior over time (Yaffee, 2003).

In the random effects model we can include time invariant variables such as gender in the model. However, in the fixed effects model these variables are absorbed by the intercept 


\section{Macrothink}

(Torres-Reyna, 2007). Since ERM adoption is a time invariant variable in our study we selected the random effects model for our analysis.

The equation of the random effectsmodel in our study is as follows:

Tobin's $Q_{i t}=\beta_{0}+\beta_{1} E_{R M}+\beta_{2}$ ROA $_{i t}+\beta_{3}$ STDAit $+\beta_{4}$ LTDAit $+\beta_{5}$ Size $_{i t}+u_{i t}+\varepsilon_{i t}$

Where:

$\beta_{\mathrm{i}}$ : Beta coefficients of the model $(\mathrm{i}=1,2, \ldots . .5)$

$u_{i t}$ :Between-entity error

$\varepsilon_{\text {it }}$ :Within-entity error

\subsection{Survey}

We developed a survey questionnaire on the basis of the questionnaire used by Anne E. Kleffne, Ryan B.Lee and Bill McGannon in 2003 (University of Calgary Study) to find out if firms adopted ERM or not and obtain information about motivation to implement ERM, challenges of ERM implementation, effects of ERM adoption etc. We translated the questions of the University of Calgary Studyinto Turkish. We shared our questionnaire with the Risk Manager of Marsh Company, which provides consultation services in ERM implementation to a number of firms in Turkey and the head of the Enterprise Risk Management Association to make questionnaire more reasonable and valid. We revised our questionnaire by their views and by the opinions of field experts, namely ERM management team of a big company in the population, which is well known for its experience in ERM implementation. We sent the questionnaire to all the companies (risk managers in general) in the population through an online survey platform. Out of 130 companies, we received 29 valid responses, which correspond to a respond rate of around $22 \%$.

\section{Findings}

In this section we present the findings of panel data analysis and the survey.

\subsection{Panel Data Analysis Findings}

It appears that only 9.2\% (12 firms) of the firms analyzed are practicing ERM as we do not find any evidence that the remaining firms are practicing ERM. We used a dummy variable to identify the adoption of ERM (1 yes, 0 no). 
Table 1. DescriptiveStatisticsfor ERM $=0$

\begin{tabular}{|l|l|l|l|l|l|}
\hline Variable & Obs. & Mean & Std. Dev. & Min & Max \\
\hline Tobin's Q & 708 & .909 & 1.40 & 0 & 14.63 \\
\hline ROA & 708 & .027 & .285 & -1.11 & 6.8 \\
\hline SDA & 708 & .373 & .492 & 0 & 8.62 \\
\hline LDA & 708 & .133 & .190 & 0 & 2.47 \\
\hline SIZE & 708 & 8.20 & .731 & .69 & 9.84 \\
\hline
\end{tabular}

Table 1displays some descriptive statistics of the variables analyzed for 118 firms (Group A) which do not adopt ERM (ERM=0).

Table 2. Descriptive Statistics for ERM =1

\begin{tabular}{|l|l|l|l|l|l|}
\hline Variable & Obs. & Mean & Std. Dev. & Min & Max \\
\hline Tobin's Q & 72 & .618 & .526 & .01 & 2.27 \\
\hline ROA & 72 & .051 & .077 & -.16 & .41 \\
\hline SDA & 72 & .377 & .171 & .08 & .88 \\
\hline LDA & 72 & .163 & .108 & 0 & .42 \\
\hline SIZE & 72 & 7.80 & 1.130 & 6.39 & 9.5 \\
\hline
\end{tabular}

Table 2 displays some statistics of the variables analyzed for 12 firms (Group B) which implement ERM (ERM=1).

The study shows that Tobin's Q of Group A is higher compared to Tobin's Q of Group B firms. The Standard deviation of Group A (1.40) is higher than of Group B (.52). Profitability ratios of firms in Group B seem to be higher and less volatile or dispersed. Leverage is measured by SDA (Short term debt to asset ratio) and LDA (Long term debt to asset ratio). Though the mean values of SDA are almost the same, Group B has a lower variation compared to Group A. The results show that firms implementing ERM tend to have a higher LDA. ERM practicing firms appear to be relatively smaller in size. The findings imply that ERM practicing firms can enjoy more long term leverage as they have a higher LDA; despite they are smaller in size. 
Table 3. Findings of the Regression Model

\begin{tabular}{|l|l|l|l|l|l|l|}
\hline Tobin Q & Coef. & $\begin{array}{l}\text { Std. } \\
\text { Err. }\end{array}$ & $z$ & $\mathrm{z}>|\mathrm{z}|$ & \multicolumn{2}{|l|}{$[95 \%$ Conf. Interval] } \\
\hline ERM & -.286 & .320 & -0.89 & 0.371 & -.914 & .341 \\
\hline ROA & .234 & .130 & 1.79 & 0.073 & -.0218 & .490 \\
\hline SDA & -.255 & .128 & -1.99 & 0.046 & -.507 & -.004 \\
\hline LDA & -.838 & .286 & -2.93 & 0.003 & -1.399 & -.277 \\
\hline SIZE & -.042 & .075 & -0.56 & 0.574 & -.189 & .105 \\
\hline cons & 1.457 & .630 & 2.31 & 0.021 & .220 & 2.693 \\
\hline
\end{tabular}

We present the findings of the random effects regression model in the table above.

The overall model seems significant (Wald $\mathrm{chi}^{2}=11.74 ; \mathrm{p}=0.0385$ ). Yet, there seems to be no statistically significant relationship between firm value and ERM $(z=-0.89, p=0.371)$.

There seems to be a negative significant relationship between leverage (STDA and LTDA) and firm value. We observe no significant relationship between ROA and Tobin's Q. We also observe no relationship between firm size and Tobin's Q.

\section{Survey Findings}

As indicated before, 29 companies participated in the survey. Below we present the number of responding firms by industry.

Industry $\quad$ Number of Responding Firms

Construction $\quad 5$

Energy 5

Other $\quad 10$

Food 2

Telecommunication 2

Media 1

Petrochemical $\quad 1$

No response $\quad 3$

Total 29

26 of the respondents replied "Yes" when asked if their firm is using an Enterprise Risk Management (ERM) approach to managing risk, while 3 of them replied "No". 15 of the firms indicated that they have adopted ERM before 2011whereas 8 of them stated they 


\section{Macrothink}

Journal of Management Research

ISSN 1941-899X 2017, Vol. 9, No. 1

adopted it after 2011. 23 out of 29 respondents stated they also have a written risk management philosophy or policy. Moreover, 24 of the 29 respondents indicated that they already have risk identification processes and 23 stated they present an annual risk management report to the board of directors.

The driving forces behind adoption ERM or consideration of ERM approach are indicated as follows:

Request of the Board of Directors 18

Competition or other industry-related pressures

Stakeholder pressure

Compliance with the corporate governance principles

Pressure of the international parent company:

Other:

To the question "In your opinion, which of the following problems, if any, did you encounter or would you anticipate encountering in the decision on whether to implement an Enterprise Risk Management strategy?

Resistance from the Board of Directors

Lack of qualified personnel to implement the program

4

Need for internal control and review systems

Organizational structure or a corporate culture that discourages ERM 10

Resistance to change

Regarding the changes that have been observed since the firm adopted ERM, the replies are as follows:

Development of company-wide guidelines for risk management

More coordination with different areas responsible for risk management

More interaction and involvement in the decision making of other departments

More direct interaction with the Board or committees of the Board

More requests from the Board for information

Increased sense of responsibility to provide information to Senior Officers, the

Board, or committees of the Board

Increased awareness of nonoperational risks by operational risk management

personnel 
Increased awareness of operational risks by nonoperational risk management

personnel

An increase in the proportion of external directors on the Board

With respect to the factors which are influential in causing the changes observed with the adoption of ERM, the following factors were emphasized:

Competition or other industry-related pressures

Compliance with the corporate governance principles

Increased concern regarding Directors' and Officers' liability exposures 3

Adoption of an enterprise risk management strategy by the firm

Recently being listed on an exchange (going public)

Pressure from a majority shareholder

Out of the 29 responding firms, 23 indicated that there is Board member or top manager responsible for the supervision of risk management activities. Furthermore, 26 of the 29 firms stated that they have a distinct Risk Management Committee as well as other specific committees. 21 of the respondents indicated that they state the risk management related responsibilities in the job definitions of top managers.

Regarding the opinion of the respondents if the risk appetite of the managers comply with the strategies and objectives of the firm, 26 of the respondents stated they think they match, whereas 3 mentioned that they do no match.

23of the managers who replied indicated that risk management is the primary function of their job.

With respect to their title, titles of 8 of 23 respondents correspond to Chief Risk Officer (Corporate Risk Management Coordinator or Corporate Risk Manager), while 9 of them indicated they had a title of Risk Expert or Risk Committee Member. The remaining hold the title of accountant or Finance or Investment Relations Manager.

The participants in the survey are categorized according to their experience as follows: 16 managers have more than 7 years of experience, 8 managers have not more than 6 years of experience and 2 managers are totally new in the risk management field.17 respondents have a master or doctorate degree while others have a bachelor's degree.

19 managers indicated that they had experience in the field of risk management, whereas 4 managers indicated they had experience in field of finance or accounting and 2 managers in the field of insurance. The remaining 4 have experience in general management or other fields.

In terms of to whom the risk manager reports, 14 managers said they reported to the Finance Manager (11 of 14) or Accounting Manager (3 of 14), while only 6 managers said they 
reported to the General Manager.

To the question "Does your firm have a "Chief Risk Officer" or an equivalent position? (A Chief Risk Officer is a corporate executive in charge of assessing and planning for all potential risks (both operational and nonoperational) faced by the company), 23 of the respondents replied "Yes", while only 6 replied "No".

To the question regarding which "nonoperational" or "financial" risks are actively monitored by the department that handles operational risk management, here are the number of responses received.

$\begin{array}{ll}\text { Asset Value Risk } & 4 \\ \text { Commodity Price Risk } & 6 \\ \text { Exchange Rate Risk } & 12 \\ \text { Interest Rate Risk } & 7 \\ \text { Political Risk } & 8 \\ \text { Third-party Credit Risk } & 7 \\ \text { Other } & 11\end{array}$

\section{Conclusion}

Enterprise Risk Management (ERM) is an integrated risk management approach, which considers risks in the context of business strategy and manages them with a portfolio perspective focusing on critical risks, through defined risk responsibilities and strong risk monitoring. Importance of ERM has increased especially after 2008 financial crisis. ERM enhances company performance by reducing the cost of capital, improving confidence of investors and also improving rating of the firm. However, our findings suggest that there seems to be no significant relationship between firm value and ERM for 130 manufacturing firms in Turkey using data of 2008-2013. An explanation could be that the effect of ERM is not reflected on firm value yet, since most firms have been implementing it for a short period of time and also it takes a long time for ERM practices to be reflected on company performance and firm value. Furthermore, the firms which adopted ERM comprise only 9.2\% of the population, which is one of the most important limitations of our study. Another important limitation is that the year which ERM was adopted is different at the firm level. However, when we confirmed that a firm implements ERM, we included all data of those firms implementing ERM, starting from 2008 as data belonging to an ERM implementing firm, although some of them adopted it in later years.

With respect to the ERM practices of manufacturing companies in Turkey, responses of participants imply that most companies which adopted ERM have a board member or top manager responsible for supervision of risk management activities. Moreover, most of them have a written risk management philosophy or policy, risk identification processes and an annual risk management report presented to the board of directors. They also have CRO post with experience in the field of risk management, who usually reports to the Finance or Accounting Manager. The key driving forces for ERM adoption seem to be request of Board of Directors and compliance with corporate governance principles. The most important 
changes observed with the implementation of ERM are compliance with corporate governance principles, more coordination with different areas responsible for risk management and development of companywide guidelines for risk management. The most important problems encountered in the implementation of ERM seems to be resistance to change and organizational structure or corporate culture discouraging ERM. Yet, the implications derived from the survey responses cannot be generalized as the participants include only 26 firms that implement ERM.

Future research on this topic can utilize a more comprehensive dataset which includes data of ERM implementing firms to account for ERM engagement starting from the date ERM was adopted. We also suggest that researchers can undertake in-depth interviews with firms that have a long experience of ERM engagement to obtain detailed information about basic motives of adoption of ERM, effects of ERM practices and ERM implementation challenges.

\section{References}

Allayannis, G., \& Weston, J. P. (2001). The use of foreign currency derivatives and firm market value. Review of Financial Studies, 14(1), 243-276. http://doi.org/10.1093/rfs/14.1.243

Banham, B. Y. R., \& Basics, E. R. M. (2004). Enterprising views of risk management. Journal of Accountancy, 197(6), 65-72.

Barton, T. L., Shenkir, W. G., \& Walker, P. L. (2002). Making enterprise risk management pay Off. Financial Times/Prentice Hall PTR. Retrieved from http://books.google.nl/books?id=ZdpPil_wyJgC

Baxter, R., Bedard, J. C., Hoitash, R., \& Yezegel, A. (2013). Enterprise risk management program quality: determinants, value relevance, and the financial crisis. Contemporary Accounting Research, 30(4), 1264-1295. http://doi.org/10.1111/j.1911-3846.2012.01194.x

Beasley, M., Pagach, D., \& Warr, R. (2008). Information conveyed in hiring announcements of senior executives overseeing enterprise-wide risk management processes. Journal of Accounting, Auditing and Finance, 23(3), 311-332. http://doi.org/10.1177/0148558X0802300303

Colquitt, L. L., Hoyt, R. E., \& Lee, R. B. (1999). Integrated risk management and the role of the risk manager. Risk Management and Insurance Review, 2(3), 43-61. http://doi.org/10.1111/j.1540-6296.1999.tb00003.x

COSO - Executive Summary. (2004). Enterprise risk management — integrated framework. New York, 3(September), 1-16.http://doi.org/10.1504/IJISM.2007.013372

Cummins, J. D., Lewis, C. M., \& Wei, R. (2006). The market value impact of operational risk events for U.S. banks and insurers. Journal of Banking and Finance, 30(10), 2605-2634.

Dabari, I. J., \& Saidin, S. Z. (2014). A theoretical framework on the level of risk management implementation in the nigerian banking sector: the moderating effect of top management support. Procedia - Social and Behavioral Sciences, 164(August), 627-634. 
http://doi.org/10.1016/j.sbspro.2014.11.156

Fraser, J. R. S., \& Simkins, B. J. (2007). Ten common misconceptions about enterprise risk management. Journal of Applied Corporate Finance, 19(4), 75-81. Retrieved from10.1111/j.17456622.2007.00161.x\nhttp://w3.bgu.ac.il/lib/customproxy.php?url=http://se arch.ebscohost.com/login.asp $x$ direct $=$ trueanddb $=$ bthandAN $=27940548$ andsite $=$ edsliveandau thtype $=$ ip, uidandcustid $=$ s4309548andgroupid $=$ mainandprofile $=$ eds

Fraser, J., \& Simkins, B. (2010). Enterprise risk management. John Wiley and Sons.

Gates, S., Nicolas, J.-L., \& Walker, P. L. (2012). Enterprise risk management: a process for enhanced management and improved performance. Management Accounting Quarterly, 13(3), $28-38$. Retrieved from http://ezproxy.library.capella.edu/login?url=http://search.ebscohost.com/login.aspx?direct=tru eandd $=$ bthand $A N=78173163$ andsite $=$ ehost-liveandscope $=$ site

Gatzert, N., \& Martin, M. (2015). Determinants and value of enterprise risk management: empirical evidence from the literature. Risk Management and Insurance Review, 18(1), 29-53. http://doi.org/10.1111/rmir.12028

Hillson, D. (2002). Extending the risk process to manage opportunities. International Journal of Project Management, 20(3), 235-240. http://doi.org/10.1016/S0263-7863(01)00074-6

Hoyt, andLienberg. (2011). The value of enterprise risk management. Journal of Risk and Insurance.

Hoyt, R. E. (2003). The determinants of enterprise risk management: evidence from the appointment of cheif risk office. Risk Management and Insurance Review, 6(1), 37-52.

Jorion, P. (2009). Risk management lessons from the Credit Crisis. European financial Management, 15(5), 923-933. http://doi.org/10.1111/j.1468-036X.2009.00507.x

Lam, J. (2014). Enterprise risk Management: from incentives to controls. Wiley. Retrieved from https://books.google.com/books?id=CQGJAgAAQBAJandpgis=1

Lang, L. H. P., \& Stulz, R. M. (1994). Tobin's q, corporate diversification, and firm performance. Journal of Political Economy. http://doi.org/10.1086/261970

Liebenberg, A. P., \& Hoyt, R. E. (2003). The determinants of enterprise risk management: evidence from the appointment of chief risk officers. Risk Management and Insurance Review, 6(1), 37-52. http://doi.org/10.1111/1098-1616.00019

Lin, Y., Wen, M., \& Yu, J. (2011). Enterprise risk management: strategic antecedents, risk integration and performance. North American Actuarial Journal, 16(702), 0-48.

LMcShane, M. K., Nair, A., \& Rustambekov, E. (2011). Does enterprise risk management increase firm value?: Journal of Accounting, Auditing and Finance. http://doi.org/10.1177/0148558X11409160

Meulbroek, L. K. (2002). Integrated risk management for the firm: a senior manager's guide. 


\section{Macrothink}

Journal of Management Research

ISSN 1941-899X

2017, Vol. 9, No. 1

Journal of Applied Corporate and Finance, 14, 56-70. http://doi.org/10.2139/ssrn.301331

Miccolis, J. A., Hively, K., Merkley, B. W., \& Perrin, T.-T. (2001). Enterprise risk management: trends and emerging practices. Institute of Internal Auditors Research Foundation. Retrieved

from hthttps://www.amazon.com/Enterprise-Risk-Management-Emerging-Practices/dp/089413458 2

Moeller, R. R. (2011). COSO Enterprise risk management. Risk management (2nd ed). Hoboken, NJ, USA John Wiley and Sons, Inc. http://doi.org/10.1002/9781118269145

Nocco, B. W., \& Stulz, R. M. (2006). Enterprise risk management: theory and practice. Journal of Applied Corporate Finance, 18(4), 8-20. http://doi.org/10.1111/j.1745-6622.2006.00106.x

Smithson, C. W., \& Simkins, B. J. (2005). Does risk management add value? A survey of the evidence. Journal of Applied Corporate Finance, 17(3), 8-17. http://doi.org/10.1111/j.1745-6622.2005.00042.x

Song, G., \& Kemp, S. T. (2013). Does the existence of an enterprise risk management (Erm) program influence the existence of material weaknesses in internal control over financial reporting? British Accounting Review, 38(4), 387-404. http://doi.org/10.1016/j.bar.2006.05.002

Torres-Reyna, O. (2007). Panel data analysis fixed and random effects. Princeton University, (December). RMarshetrieved from http://dss.princeton.edu/training/Panel101.pdf

Walker, P. L., Shenkir, W. G., \& Barton, T. L. (2002). Enterprise risk management: pulling it all together. Institute of Internal Auditors Research Foundation.

Yaffee, B. R. (2003). A primer for panel data analysis. Connect Information Technology at NYU, (September), 1-11. 